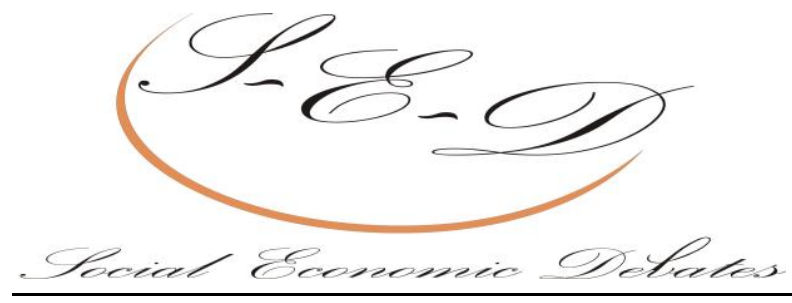

\title{
Green economy - an opportunity during the global crisis
}

\author{
Constantin Constantinescu \\ Ph. D. student, Bucharest University of Economic Studies, \\ Email: constant.constantinescu@gmail.com
}

\begin{abstract}
When talking about natural capital is often difficult to relate to it as a form of capital similar to $\mathrm{h}$ financial capital or human capital. The difficulty arises mainly as a result of the diversity of forms that natural capital takes and due to the fact that it is not always possible for its value to be expressed in monetary terms. Some of the goods and services provided by ecosystems, such as wood, fish or berries, are normally traded on the market and their monetary value is known. For others, such as the costs of eliminating the effects of natural disasters, for example, the monetary value can be estimated. How one could also estimate the value of ecosystem services in relation to the willingness to pay for them by those who take benefit of them, as in the case of tourism, for example. Substitution between different forms of capital is questionable in this regard, especially because in addition to its intrinsic value, the goods and services provided by ecosystems provide a wide range of socio-economic benefits out of which most cannot be replaced by technology solutions. In this context, the green economy development, which implies increasing the energy efficiency and also the mode of resource exploitation, is seen as an opportunity and a necessity at the same time. Investments which consider objectives such as reducing pollution and carbon emissions lead to, on one hand, to increasing income and to an increase in the level of employment, and on the other hand, to preventing the degradation of ecosystem goods and services and biodiversity.
\end{abstract}

Keywords: green economy, natural capital, economic crisis.

\section{Introduction}

In order to protect the biodiversity and ensure the framework for a sustainable economic development it is necessary to adopt a sectorial approach, which would consider high risk areas and to act upon them with priority. The reaction adapted to the problems' severity which affect the natural capital can lead to settling common objectives and concerted action to solve the problems methods approved at local, national, or international level. Such a strategy allows more efficient resource involvement and a harmonization of the allocation and use of them. A fast degradation of ecosystems, phenomenon called more frequently "the sixth extinction ", with direct reference to the devastating impact of economic development on biodiversity, which represents totally human [ir]responsibility. With all that and despite increasing the degree of concern among both professionals and the population, the number of efficiently protected habitats is still extremely reduced, even in the areas declared protected areas. Ecosystems are affected by major changes as habitats are degraded and fragmented due to urbanization, changing the scope of land usage, pollution and overexploitation. Meanwhile, a significant number of habitats are destroyed as a result of climate change caused by emission of greenhouse gases. The degradation of natural capital is directly reflected in the quality and quantity of food produced, in the increased risk of natural disasters and the health of the population. 


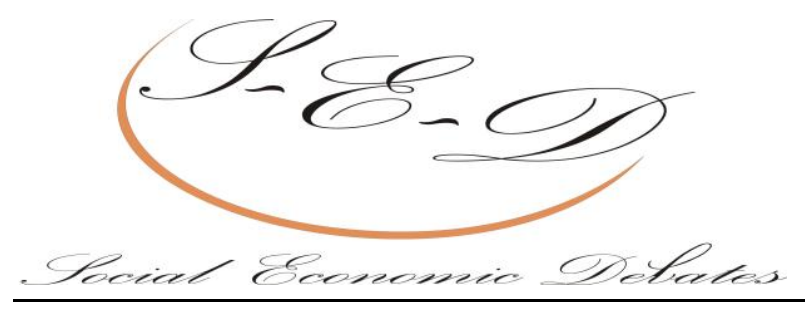

\section{Economic theory and practical suitability}

The economic theory has given a special attention to the natural capital only recently, although one of the first forms of capital used was natural capital, with respect to the land. The nature of public goods assigned to some elements of natural capital has created difficulties in assessing the value of natural capital, of the non- tradable goods and services provided by nature. Most often were counted the destructions of natural capital caused by environmental externalities generated by the industry. Therefore the economic policies that took into consideration the environment focused on the internalization of these externalities, taking into consideration for this purpose, incentives as well as punitive financial instruments. Also, in our opinion the view according to which as the resources will be used they will also have a gradual substitution, as a result of technological progress and have a continuous increase in the efficiency of their usage along with the economic growth process, it is optimistic to an extent which is not justified.

In the actual understanding of natural capital it represents the extension of the economic concept of capital for the goods and services provided by nature. It is generally regarded as an indispensable stock of resources and benefits provided by ecosystems, which produces a flow of environmental useful goods and services. Among the services provided by the natural capital one can count waste recycling, soil erosion control, water retention and creating hydrological reserve holdings. Currently, there are two errors which occur with regards to the value of natural capital. One of them is trying to express the value of natural capital only in monetary terms. This results some times in ignoring the value of the natural capital for making things simpler and due to the lack of accurate assessment tools, and other times the value of natural capital is assessed only by looking at a part of it. The other error establishing the value of the natural capital is the exclusive assessment of some goods or services provided by nature, whose market value can be determined easily. We shouldn't leave aside; however, the fact that the structure and diversity of ecosystems represent components of the natural capital, so that providing a flow of services by nature requires an overview of how ecosystems work as a whole.

The ecosystems stock and flow of goods and services provided by ecosystems which represent the natural capital is the foundation without which the global wealth creation would not be possible. The exploitation of natural capital produce effects which cannot be found in the balance sheets of businesses. However, the environmental impact can affect climate, security of elementary resources for survival of the population, food resources, water and energy resources. On the other hand, the consequences of irrational exploitation of the natural resources affect ecosystems' resources at a global level. Rational exploitation of land and forests leads to water shortages for hydroelectric power station and agriculture, to a decrease in the storage capacity of $\mathrm{CO}_{2}$ and to an increase in emissions of greenhouse gases.

In times of economic crisis and in the context of globalization more and more diverse and serious consequences of increasingly irrational use of natural capital have emerged. The consumption of oil palm fruit increased 8 times in the last 30 years, being the most frequent oil produced in the world, surpassing the production of soybean and rapeseed oil. The deforestation in Malaysia and Indonesia with the purpose of obtaining palm oil to have negative consequences 


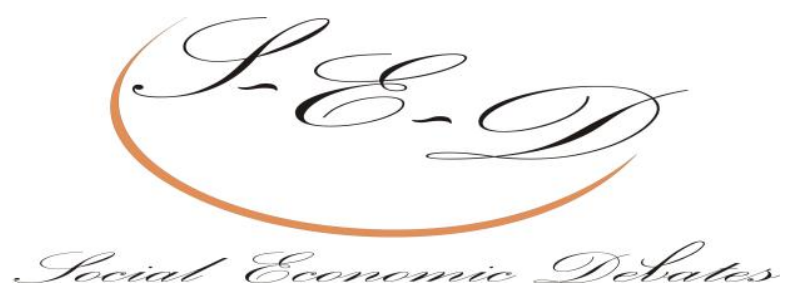

on ecosystems, endangering orangutans habitats ${ }^{1}$. The impact of the activity of oil producing companies on biodiversity has created reactions which have damaged the image and caused losses for those respective companies. Reputational risk can cause adverse effects in financial terms, leading to a decrease in share price of a company, a lower rating on the stock market or higher interest rates for loans. This is how the companies that have achieved certificates for products made through sustainable industrial processes have gained an advantage, as examples one can count the exploitation of rubber trees, or caviar exploitation.

\section{Biodiversity and sustainable economic development}

The decrease in the stock of resources and exponential growth of the population creates a growing pressure on global natural capital, which has determined the increase in of its financial value during the last years. The effect is reflected in the firms' financial plans for future periods. The price increases for raw materials leads to shrinking profits for many businesses and creates difficulties for supply chains. This situation represents a risk factor for investors, which needs to be considered together with other risk factors in the context of economic crisis. The condition of public goods of many of the natural capital components makes it difficult to estimate the price evolution. In the same context, sustainable capital investment seeks to impose a competitive market. „Sustainable companies are those that create long-term sustainable value by building economic, social and environmental capital to provide ever better goods and services in a way that is profitable, ethical and respects the environment, individuals and the communities in which they operate."(Tomorrow's company)

The global crisis has determined the financial markets to examine more carefully the risk exposure, which made the orientation towards sustainable capital investments be more frequent. The companies' actions became sustainable along with the increase in companies' capacity to integrate the natural capital which they have and along with including the sustainability criteria in evaluating the company. The climate changes and extreme weather conditions which became more and more frequent were identified as the biggest market failure in history. As a consequence, the investors began to realize more and more how important are the consequences of climate change on portfolio performance and how important is the effect of carbon dioxide on the economy. This is directly related to individual consumption, with the level of energetic intensity of production and to how carbon - intensive energy is the energy used. Previous financial crises, just as this one, have confirmed the vulnerability of financial markets to shocks. A sharp rise of prices for some raw materials, or resources belonging to natural capital, can cause systemic shocks in the absence of effective risk management tools, including price risk. This makes very important having a correct estimation of the importance of goods and services offered by the ecosystem, including the social and political responsibility, and the value of natural capital conservation programs should increase in order to allow an improvement in the financial stability in socio -economic context.

\footnotetext{
${ }^{1}$ http://www.lexpress.fr/styles/saveurs/nous-consommons-toujours-autant-d-huile-de-palme_1095083.html
} 


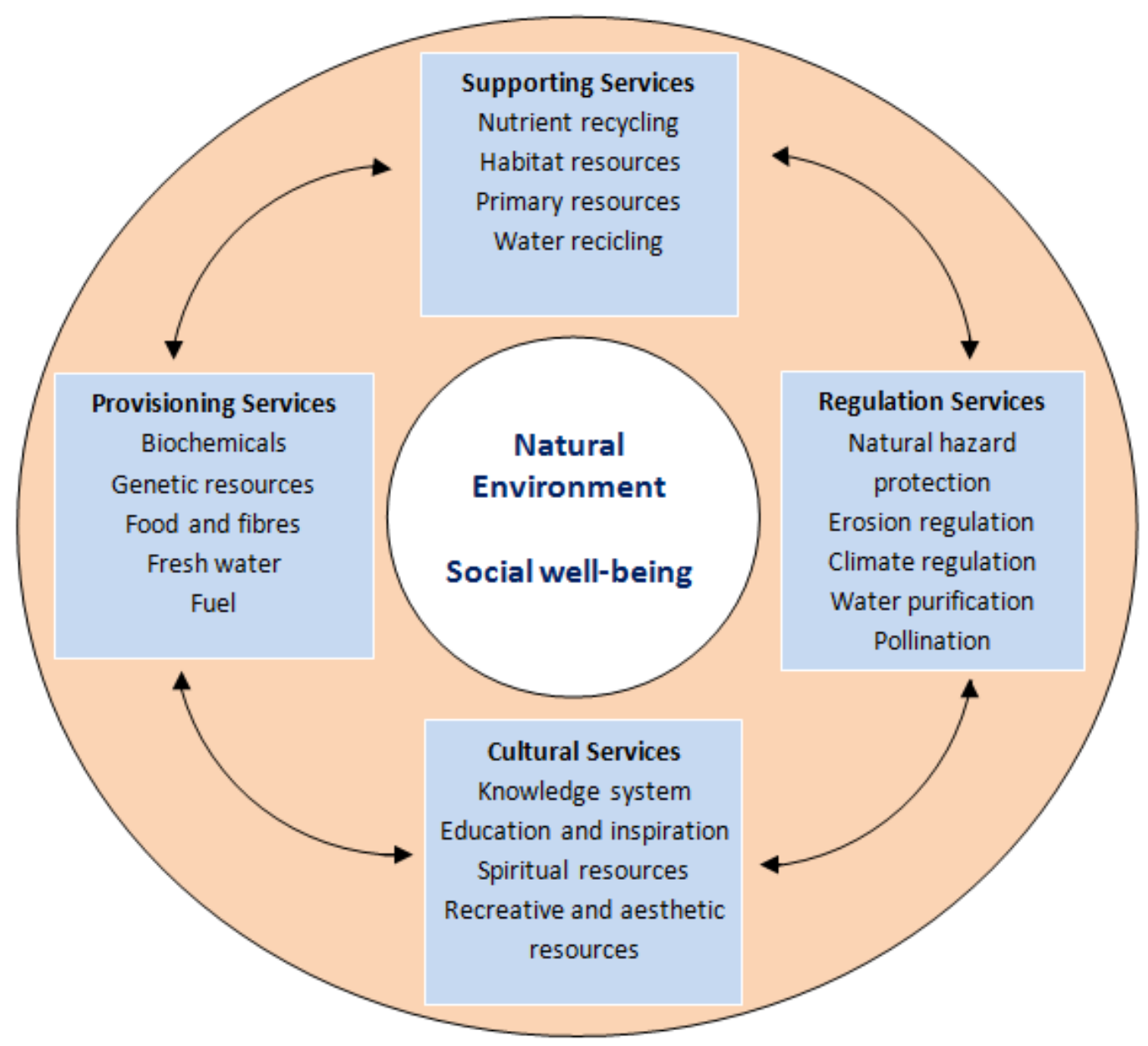

Figure 1. Ecosystem services (Source: OECD 2013)

The investment in the natural resources exploitation, mining projects, for example, or hydra-electric power stations or similar constructions have to consider among other types of risks also the environmental risks. Another area of risk for the company is represented by the external effects of their activities and the costs they incur for their internalization. This is why they are related to policies regarding economic sectors which are environmentally sensitive, such as industries with a high degree of pollution, such as chemical industry, and mining industry. The economic crisis has prompted investors to grow the degree of prudence for their decisions, but it wasn't yet considered a systematic approach in the way in which the financial institutions and insurance companies must consider the risks dependent on natural capital. During the economic crisis the pressures on natural capital stock, which was decreasing, were larger and were overlapping the problems created by the economic downturn. Therefore, economies faced decreasing water resources from aquifers layers and surface waters. As a consequence a sizeable decline of drinkable water was registered along with a decrease in the production of energy from hydropower and fishing industry. This contributed to the instability of global financial markets 


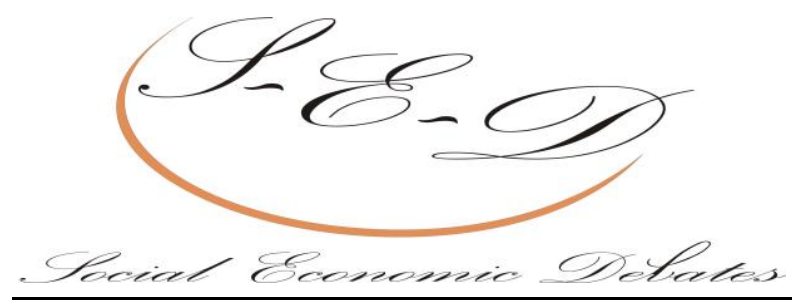

and increased price volatility.

\section{During crisis risks increase}

The Risks generated by the degradation of natural capital through the decrease in the amount of goods and services offered by ecosystems are important for companies, therefore understanding these risks and limiting them can lead to an important market advantage. Opportunity losses compensation caused by the global crisis can be created by generating additional profits through businesses transformation in sustainable businesses. Considering this on a long term, the approach may have a role in stabilizing markets that are dependent on natural resources. This requires the introduction of natural capital in the accounting standards so its contribution can be highlighted for the output and make it easier, in the same time, to assess the profitability of companies. However, with increase in the energy and raw material prices, investment in new technologies, which are more efficient, reduce environmental impact of industrial processes.

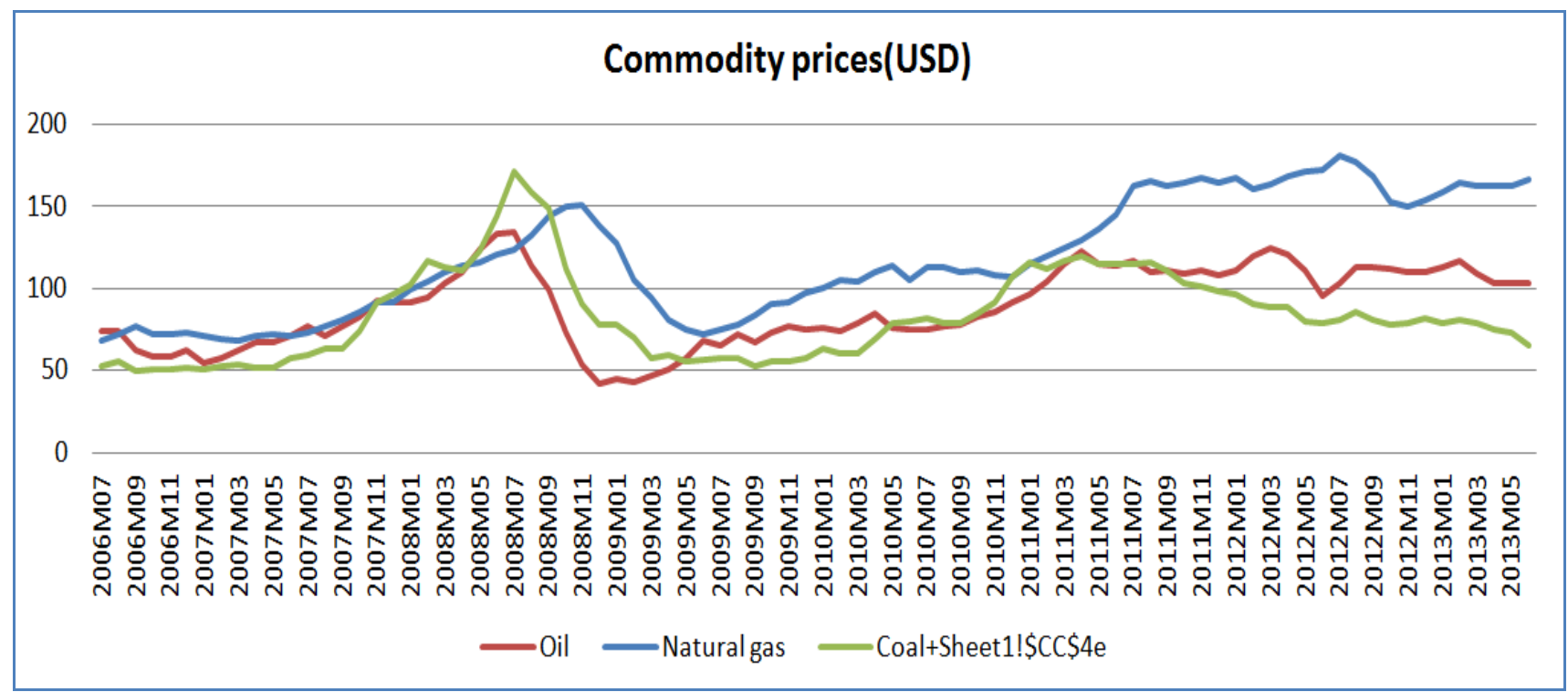

Figure 2. Commodity price during the economic crisis (Source: World Bank)

In order to preserve the natural capital sustainable economic reforms are necessary, reforms which are based on political decisions, which need to consider the economic crisis as an opportunity for a paradigm shift. The current economic model, built on the premises that it is possible to have an unlimited increase in the exploitation of resources, has generated an ecological deficit which is constantly growing. The austerity measures imposed to countries which were in a crisis have a major negative impact on the environment. Also environmental remediation costs are rising, which leads to the conclusion that it is necessary to adopt measures to internalize the environment externalities trough effective policies, based on indicators that reflect the status of natural capital. The efficiency of the measures taken for economic adjustment, taken as a response to the crisis, depends on their level of sustainability. Some 


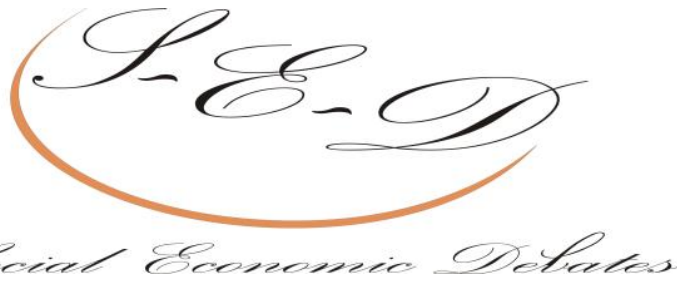

measures, such as those referring to increasing the level of efficiency for usage of energy, generate besides financial savings, also conditions for preserving the natural capital. In order to emphasize them, special attention needs to be given to the economic indicators which are more comprehensive than GDP or GNI, because it is difficult to estimate the value of goods and services provided by ecosystems, which is the case for species diversity. Therefore, it is important to revise the role of nature in the production of food, fuel, fiber and construction materials, forcing us to question whether the economic growth is not achieved at the expense of human well-being.

\begin{tabular}{llllllll}
\multicolumn{2}{c}{ Bovine meat price (USD/T) } & \multicolumn{2}{c}{ Maize price (USD/T) } & \multicolumn{2}{c}{ Rice price (USD/T) } & \multicolumn{2}{c}{ Wheat price (USD/T) } \\
2006 & $3,803.25$ & 2006 & 119.56 & 2006 & 311.24 & 2006 & 199.65 \\
2007 & $4,023.00$ & 2007 & 160.86 & 2007 & 334.45 & 2007 & 263.80 \\
2008 & $4,325.08$ & 2008 & 206.43 & 2008 & 697.48 & 2008 & 344.58 \\
2009 & $3,896.58$ & 2009 & 169.42 & 2009 & 583.48 & 2009 & 235.69 \\
2010 & $4,377.75$ & 2010 & 195.26 & 2010 & 520.00 & 2010 & 240.81 \\
2011 & $4,516.17$ & 2011 & 289.25 & 2011 & 566.24 & 2011 & 330.08 \\
2012 & $4,912.58$ & 2012 & 270.42 & 2012 & 590.39 & 2012 & 327.15 \\
2013 & $5,351.29$ & 2013 & 248.20 & 2013 & 539.95 & 2013 & 324.37
\end{tabular}

Tabel 1. The evolution of food prices during the economic crisis (Source: FAO)

Comparing the huge amounts spent to rescue the banking system with the amounts spent for saving the ecosystems shows the inconsistency of public politics.

During the economic crisis the industrial activity has considerably decreased and so has the energy consumption, but the cheap energy obtained from fossil fuels, greenhouse gases generator has been used. The carbon market works slow, and the interests and asymmetric points of view, make the effort of reducing the current carbon emissions harder. On the other hand, the pigouvian principle states that for the negative environmental externalities the polluters should pay a price equal to the marginal social damage they cause. Thus, they will not pollute beyond the point where marginal cost for reducing the emissions is lower than that price, thus balancing the social cost and social benefit. In the context where the largest part of this amount of greenhouse gases has historical origins and the responsibility belongs today to states that have a high level of industrialization, the problem of taking the responsibility occurs.

Also the discrepancy between the carbon price at the moment when it is calculated and the carbon price at the moment of greenhouse gases accumulating in the future needs to be considered.

As a consequence the investment decisions in the energy field need to consider the carbon price in the future, which is expected to grow in terms real, no matter if talking about energy produced from renewable sources, or talking about fossil fuels. 


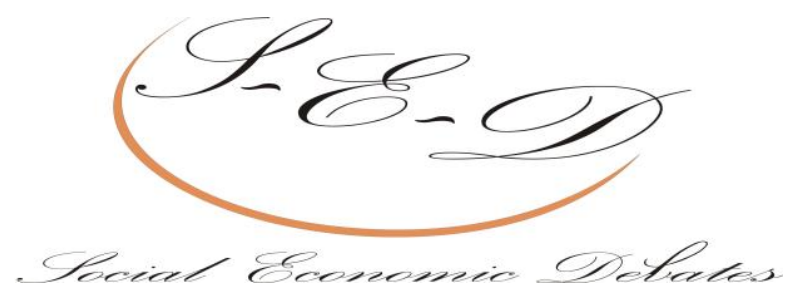

The constant increase in the price of fossil fuels is not likely to compensate the upgrade of carbon emission price, but it will increase the resistance to it. In addition to the mentioned measures, stimulants for reducing the impact on the environment are considered, the stimulants can be received for example by tropical countries for stopping, or reducing the exploitation of fossil fuel. The irrational exploitation of forests is responsible of $12 \%$ of carbon emissions ${ }^{2}$.

\section{Conclusions}

The global economic crisis has created conditions for the emergence of new perspectives on economic growth in the context of sustainable development. Theoretical and practical confrontation between economic growth theory and the theory of conservation of the natural environment revealed some unknown, uncertainties and interpretation errors. Although it is often used by economists, the term " natural capital " is interpreted differently by users and therefore the approaches about its efficient use are different, ranging from proposals to limit growth in the purpose of the conservation of natural capital to liberal attitudes based on the principle of neoclassical theory letting prices to establish economic and social importance of the environment. The global crisis has demonstrated that equilibrium between economic growth and reducing environmental impact is difficult in conditions of instability. Consequently, the problem of finding the optimal level of balance between social benefits of development and costs of environmental protection is intractable when the economic variables know a high volatility and political decision must to take into account more the social factor. Global economy during the crisis has shown that the solution represented by measures to reduce the rate of deterioration of ecosystems is consistent only under conditions in which is accompanied by investment in recovery of natural capital and the environment is integrated by this way in the whole economic and social process. It outlines a new model of development in which politico- economic-financial system can positively influence natural capital stocks by increasing the quality of policy makers and investment in knowledge capital.

\section{References}

Blaug, M. (2007). Teoria economică în retrospectivă (pp. 631-642). Bucureşti, Romania, Didactică şi Pedagogică Publishing House.

Bran, F. (2002). Degradarea ecosistemelor (silvicultură şi turism): implicaţii economice (pp. 85106). Bucureşti, Romania, Academia de Studii Economice Publishing House.

Câmpeanu, V. \& Collective (2004). Dimensiunea europeană şi mondială a dezvoltării durabile (pp. 37-42). Bucureşti, Romania, Expert Publishing House.

Chambers, D. ( 2003). Technical comments on the feasibility study and the description of the Roşia Montană Project. Bozeman, MT: Center for Science in Public Participation.

Ciobotariu, V. \& Socolescu, A. (2008). Poluarea şi protecţia mediului (pp. 127-144), Bucureşti, Romania, Economica Publishing House.

\footnotetext{
${ }^{2}$ http://biology.duke.edu/jackson/ng09.pdf
} 


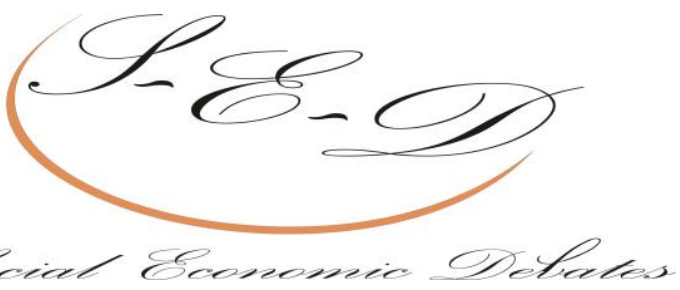

Cohen, D. (1997). Bogăţia lumii, sărăcia naţiunilor (pp. 84-91). Bucureşti, Romania, Economica Publishing House.

Constantinescu, N. N. (1976). Economia protecţiei mediului natural (pp. 119-152). Bucureşti, Romania, Politica Publishing House.

Dornbusch, R., Fischer, S. \& Startz, R. (2007). Macroeconomie (pp. 23-38). Bucureşti, Romania, Economica Publishing House.

Moran, R. E. (2006). Review of the Rosia Montana Environmental Impact Assessment. Report with a focus on water and water quality-related issues", "No Dirty Gold" Campaign , Washington, DC: Earthworks Organization.

Negrei, C. (2004). Economia şi politica mediului - ediţie revăzută (pp. 13-24, 45-58, 83-100). Bucureşti, Romania, Academia de Studii Economice Publishing House.

Ostrom E. (2007). Guvernarea bunurilor comune (pp. 16-23). Bucureşti, Romania, Polirom Publishing House.

Pohoaţă, I. (2003). Filosofia economică şi politica dezvoltării durabile (pp. 65-96). Bucureşti, Romania, Economica Publishing House.

Rojanschi,

V.http://www.biblioteca.ase.ro/catalog/rezultate.php?c=2\&q=\&st=s\&loc=0\&tp1=1\&tp2=1\&tp3 $=1 \& \operatorname{tp} 4=1 \& \operatorname{tp} 5=1 \& \operatorname{tp} 6=1 \& \operatorname{tp} 7=1 \quad \& \quad$ Bran, Fhttp://www.biblioteca.ase.ro/catalog/rezultate.php?c=2\&q=\&st=s\&loc=0\&tp1=1\&tp2=1\&tp3= 1\&tp4=1\&tp5=1\&tp6=1\&tp7=1. (2004). Elemente de economia şi managementul mediului (pp. 18-42). Bucureşti, Romania, Economica Publishing House.

Soroceanu, V. (2000). Creşterea economica şi mediul natural (pp. 123-132). Bucureşti, Romania, Economica Publishing House.

Răgălie, S. \& Muscalu S. (2003, May 28). Aspects concerning the economic efficiency of the Roşia Montanã Project, Bucharest, Romania: Paper submitted to the Romanian Parliamentary Commission..

Walsh, C. E. \& Stiglitz, J. E. (2005). Economie (pp. 397-408). Bucureşti, Romania, Economica Publishing House.

Ecological University of Bucharest (EUB) - Analysis Collective (2003). Economic Development Opportunities - The Roşia Montană preliminary study (pp. 25-26), http://www.acad.ro/rosia_montana/pag_rm03_pv.htm . 